\title{
FAMILY MATTERS IN THESSALONICA $^{1}$
}

\section{Trevor J. Burke}

Recent insights of classical historians concerning the family in antiquity have generated interest in the relationship between the ancient family as a social institution and the notion of early Christian communities as 'families' or fictive kinship groups. This thesis combines these twin aspects-the family as social reality and metaphor - in order to explore the relations between Paul and the Thessalonians and the Thessalonians' relations to one another. An indepth investigation of 1 Thessalonians is justified since it is here that we find a heavy preponderance of fictive-kinship terms (e.g. father, child, nursing-mother, brother. etc.).

Chapter 1 reviews the most recent literature where attention is drawn to the brief consideration of Paul's familial metaphors within the broader social context of Pauline Christianity. As a result, some scholars (e.g. Meeks et al.) assume that the terms 'brother'/'sister' are an indication that Paul's earliest communities are non-hierarchical in structure. Others (e.g. Castelli) argue that the apostle's use of the expression 'father' is solely understood in hierarchical terms and takes little account of the composite nature of such a role. The need to situate the above family expressions in their proper socio-historical milieu and the implications this might have for Pauline usage/meaning have largely been overlooked.

The theoretical base undergirding this study, that of 'metaphor theory', is then set out. Drawing on the insights of linguists (e.g. Lakoff and Johnson) a basic working definition for metaphor is established. A cognitive approach to metaphor is pursued where metaphor is defined as understanding and experiencing one thing in terms of another kind of experience. On the basis of this definition, it is highly likely that Paul is drawing on a familiar source field (the family in antiquity) to describe Christian relations as a family. In order to grasp the sense of the familial metaphors that the apostle employs, the emphasis was upon how these terms would have been

1 Family Matters: An Exegetical and Socio-Historical Analysis of Familial Metaphors in 1 Thessalonians (Ph.D. Thesis, University of Glasgow, 2000); supervisor: Prof. John M.G. Barclay. 
heard and understood in the ancient world. Here the focus is on the presuppositions or normal social expectations of family members in antiquity.

An intensive survey of parent-child relations in the ancient world is carried out in chapters 2 and 3. A broad range of sources, literary and non-literary, are studied to ascertain the stereotypical attitudes of household members. Literary sources include Jewish (Philo, Josephus, Pseudo-Phocylides) and non-Jewish (Aristotle, Plutarch, Seneca, Musonius Rufus, Hierocles, and Epictetus) authors; non-literary evidence is taken from dream handbooks (i.e. Artimedorus) and inscriptions. A number of stock meanings or associations of the parent-child relationship are identified. Parents are expected to produce legitimate offspring and to care for them. In particular, the father-child relationship is a hierarchical one in which a father was expected to exercise authority over his offspring. Fathers are also to provide an example for their children to follow. Significantly, both parents are to love their offspring but whereas a mother's role is to nurture her children, a father is supposed to instruct them. The powerful principle of reciprocity in the ancient world meant that children were expected to love, honour, obey, and care for their parents. What is particularly striking to note in chapters 2 and 3 is that the norms or common assumptions of Jewish family members in the ancient world were little different from those of non-Jewish families at the turn of the eras.

In chapter 4 a wide range of ancient sources are studied in order to determine the conventional assessments of brotherly relations. Again a number of stock meanings of brotherly relations are identified. Some of Paul's contemporaries deem brotherly relations as so important that they treat it separately (e.g. Plutarch's Пepi $\Phi(\lambda \alpha \delta \varepsilon \lambda \phi i \alpha \varsigma)$. Of all family relationships no one was closer than a brother, hence brothers are expected to demonstrate brotherly love. Brothers are also supposed to work hard and in the interest of family harmony, and are not to tarnish the family name in view of outsiders. When sibling conflicts arise, differences are to be settled internally and common status is to take priority over the offence that has occurred. Of special note is that brotherly relations could also be hierarchical. Whilst older brothers are responsible for admonishing younger brothers, the latter are expected to honour and obey the former. Our findings concur with those in chapters 2 and 3, namely, that there is much agreement between the Jewish and non-Jewish traditions as far as brotherly relations are concerned. 
In chapter 5 Paul's role as parent (2:10-12), particularly his fatherly responsibilities towards his Thessalonian children, is examined. The apostle's role is multifarious and is fulfilled along the lines of a paterfamilias in the regulation of the affairs of the community. By so doing Paul is mirroring the expectations of fathers in the ancient world. This includes his superiority and authority, as well as the obligation to instruct and provide an example for his offspring. However, Paul's authority-especially if one accepts the original reading as $\eta \pi$ ior (2:7)-is softer and milder. Although the term 'father' is more pointed and less benign than some scholars assume, it is also a richer and more affective term than others have allowed for. In response, the Thessalonians are expected to reciprocate by obeying and showing affection towards Paul. A study of Paul's paternal functions is followed by a treatment of the unusual maternal role of Paul as nursing mother (2:7) as well as the possibility of him having described himself as an 'infant' (2:7) and an 'orphan' (2:17). The juxtaposition of these latter metaphors completes the 'family-album' which, combined with connotations of his fatherly role.

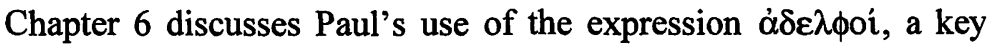
fictive-kinship term in 1 Thessalonians, occurring proportionately more often than in any other Pauline letter. This sets the scene for the exegesis of three passages which are primarily concerned with brotherly relations $(4: 3-8,4: 9-12$, and 5:12-15). In chapter 7 (4:3-8) the prevailing moral climate, as well as the coercive tone employed by Paul, makes it highly likely that he is addressing a real/potential problem of sexual immorality. In dealing with this issue, Paul's language draws clear boundary lines between the brotherhood and outsiders and emphasises the importance of holiness as the mark of the Thessalonian brotherhood. In order to avoid contamination from the outside world and to maintain the 'honour' ( $\tau \mu \mu \hat{n}, v .4)$ of the community, the apostle advocates each brother to take his own wife

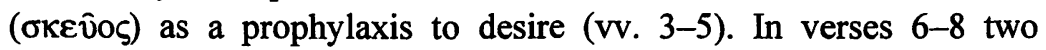
scenarios are presented: either Paul goes on to stress the disharmony caused to the community by one brother trying to take another brother's wife or he is concerned lest a brother should try to cheat another brother in a business or inheritance matter. Both make good sense against the background of sibling expectations.

The investigation then discusses how Paul deals with the related aspects of $\phi 1 \lambda \alpha \delta \varepsilon \lambda \phi i \alpha$ and work in chapter $8(4: 9-12)$. Most of the Thessalonian brothers are showing $\phi i \lambda \alpha \delta \varepsilon \lambda \phi_{i} \alpha$ and Paul even 
commends them for demonstrating this to other brothers unknown to them. However, such praise is qualified because some brothers who were opting out of their work-related responsibilities, presumably to engage in evangelism, were becoming over-dependent upon others who continued to work. This was causing a strain on relations as well as colouring the perception of outsiders (oi $\varepsilon \xi \omega$, v. 12). In order to resolve the internal tensions, Paul calls upon these brothers to curtail their evangelistic activities and return to work. The apostle is not averse to brothers showing brotherly love but neither does he want certain brothers sponging off other brothers. Thus, $\phi i \lambda \alpha \delta \varepsilon \lambda \phi i \alpha$ functions as a corrective measure or counter-strategy by putting restraints upon how this concept is understood. If Paul's advice to these wayward brothers is heeded, it will not only enhance the honour of the brotherhood, but of the entire Pauline family too.

In chapter 9 (5:12-15) Paul addresses similar issues as in 4:9-12

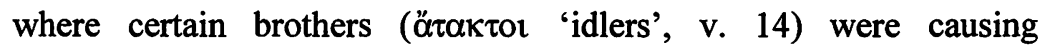
disharmony (v. 13b) by refusing to work. These same brothers were also at loggerheads with outsiders and may have engaged in retaliation against them. Paul seeks to resolve the (internal and external) conflicts through the proper ordering of the affairs of the brotherhood. The difference in seniority between the brothers-'ordinary/led brothers' (vv. 12-13) and 'leading brothers' (vv. 14-15)-a view consistent with brotherly relations in the ancient world-means that the latter are given 'to rule' ( $\pi \rho$ oí $\sigma \tau \mu \mathrm{l})$ over the brotherhood. As such they are to be acknowledged, held in the highest respect, and loved by the rest. The leading brothers are to admonish the 'idlers' and by urging them to return to work intend to shame them into seeking the welfare of the whole community, as opposed to pursuing their own individual path. Attention is drawn to the difference in rank between the brothers which coupled with the hierarchical relations between Paul and the Thessalonians, could mean that rather than viewing these nascent churches as having shifted away from a non-hierarchical structure, on the strength of this evidence-Paul's earliest extant letter and the earliest Christian writing - it would appear they never were entirely non-hierarchical. 